University of Montana

ScholarWorks at University of Montana

$10-2005$

\title{
Linking Demographic Effects of Habitat Fragmentation Across Landscapes to Continental Source-Sink Dynamics
}

P. Lloyd

Thomas E. Martin

University of Montana - Missoula, tom.martin@umontana.edu

R. L. Redmond

U. Langner

M. M. Hart

Follow this and additional works at: https://scholarworks.umt.edu/wildbio_pubs

Part of the Life Sciences Commons

Let us know how access to this document benefits you.

\section{Recommended Citation}

Lloyd, P.; Martin, Thomas E.; Redmond, R. L.; Langner, U.; and Hart, M. M., "Linking Demographic Effects of Habitat Fragmentation Across Landscapes to Continental Source-Sink Dynamics" (2005). Wildlife Biology Faculty Publications. 14.

https://scholarworks.umt.edu/wildbio_pubs/14

This Article is brought to you for free and open access by the Wildlife Biology at ScholarWorks at University of Montana. It has been accepted for inclusion in Wildlife Biology Faculty Publications by an authorized administrator of ScholarWorks at University of Montana. For more information, please contact scholarworks@mso.umt.edu. 


\title{
LINKING DEMOGRAPHIC EFFECTS OF HABITAT FRAGMENTATION ACROSS LANDSCAPES TO CONTINENTAL SOURCE-SINK DYNAMICS
}

\author{
Penn Lloyd ${ }^{1}$ Thomas E. Martin, Roland L. Redmond, Ute Langner, and Melissa M. Hart \\ USGS Biological Resources Discipline, Montana Cooperative Wildlife Research Unit, University of Montana, \\ Missoula, Montana 59812 USA
}

\begin{abstract}
Forest fragmentation may cause increased brood parasitism and nest predation of breeding birds. In North America, nest parasitism and predation are expected to increase closer to forest edges because the brood-parasitic Brown-headed Cowbird (Molothrus ater) and generalist nest predators often enter the forest from adjoining developed (largely agricultural) habitats. Yet the abundance of brood parasites and nest predators at the patch scale may be strongly constrained by the total area of developed habitat at landscape scales. The scale and extent of landscape effects are unclear, however, because past studies were mostly conducted within local landscapes rather than across independent landscapes. We report replicated studies from 30 independent landscapes across 17 states of the United States that show that nest parasitism is strongly affected by fragmentation at a $20 \mathrm{~km}$ radius scale, equivalent to the maximum foraging range of cowbirds. Nest predation is influenced by both edge and landscape effects, and increases with fragmentation at a $10 \mathrm{~km}$ radius scale. Predation is additive to parasitism mortality, and the two together yield decreased population growth potential with increasing forest fragmentation at a 10 $\mathrm{km}$ radius scale for 20 of 22 bird species. Mapping of population growth potential across continental landscapes displays broad impacts of fragmentation on population viability and allows geographic prioritization for conservation.
\end{abstract}

Key words: brood parasitism; edge effects; forest fragmentation; Hylocichla mustelina; landscape; nest predation; population dynamics; Seiurus aurocapilla; source-sink dynamics.

\section{INTRODUCTION}

Deforestation and the conversion of forests to other land uses have paralleled the development of human societies throughout the world (Groom and Schumaker 1993). Deforestation and related fragmentation of landscapes can impinge on ecological processes that influence the population growth potential of organisms, particularly birds (Lawton 1995). For example, fragmentation may increase the abundance of generalist nest predators and the brood-parasitic Brown-headed Cowbird (Molothrus ater), which are largely associated with developed and agricultural habitats, but which also enter adjoining forest (reviewed in Thompson et al. 2002). Elevated rates of nest predation and brood parasitism as a consequence of fragmentation (Robinson et al. 1995, Donovan et al. 1997, Chalfoun et al. 2002, Stephens et al. 2003, Batáry and Báldi 2004) are hypothesized to underlie population declines by many North American songbirds (Robbins et al. 1989). Past tests of the influence of landscape fragmentation on nest predation and nest parasitism have been relatively limited in geographic scope (e.g., Robinson et al. 1995,

Manuscript received 9 August 2004; revised 10 January 2005; accepted 27 January 2005; final version received 18 February 2005. Corresponding Editor: T. R. Simons.

${ }^{1}$ Present address: DST/NRF Centre of Excellence in Birds as Keys to Biodiversity Conservation at the Percy FitzPatrick Institute, University of Cape Town, Rondebosch, 7701, South Africa. E-mail: plloyd@ botzoo.uct.ac.za
Donovan et al. 1997, Burke and Nol 2000), or have involved meta-analysis of studies with diverse experimental approaches (e.g., Chalfoun et al. 2002, Stephens et al. 2003, Batáry and Báldi 2004). Further, assessment of the net consequences of fragmentation for population growth potential has been limited to modeling studies with hypothetical inputs (e.g., Donovan et al. 1995, Donovan and Lamberson 2001, With and King 2001). Thus we lack broad and replicated assessment of the influence of landscape fragmentation on nest predation, nest parasitism, and their net consequences for population growth potential.

Broad assessment is particularly critical because the effects of fragmentation on parasitism and predation are hypothesized to operate within a spatial hierarchy that includes biogeographic, landscape, and patch-level effects (Thompson et al. 2002, Stephens et al. 2003). At the patch scale, brood parasitism and nest predation are expected to be greater closer to forest edges, as parasites and many generalist predators principally occupy agricultural habitats adjoining forest. Parasitism and predation is also influenced by the abundance of parasites and predators, which may depend on the area of agricultural habitat available in the vicinity of forest. Thus the magnitude of an edge effect is expected to be constrained by broader, landscape-scale area effects. Also, predation and parasitism may differ among major biogeographic regions as a consequence of regional differences in predator guilds (Thompson et al. 2002) 


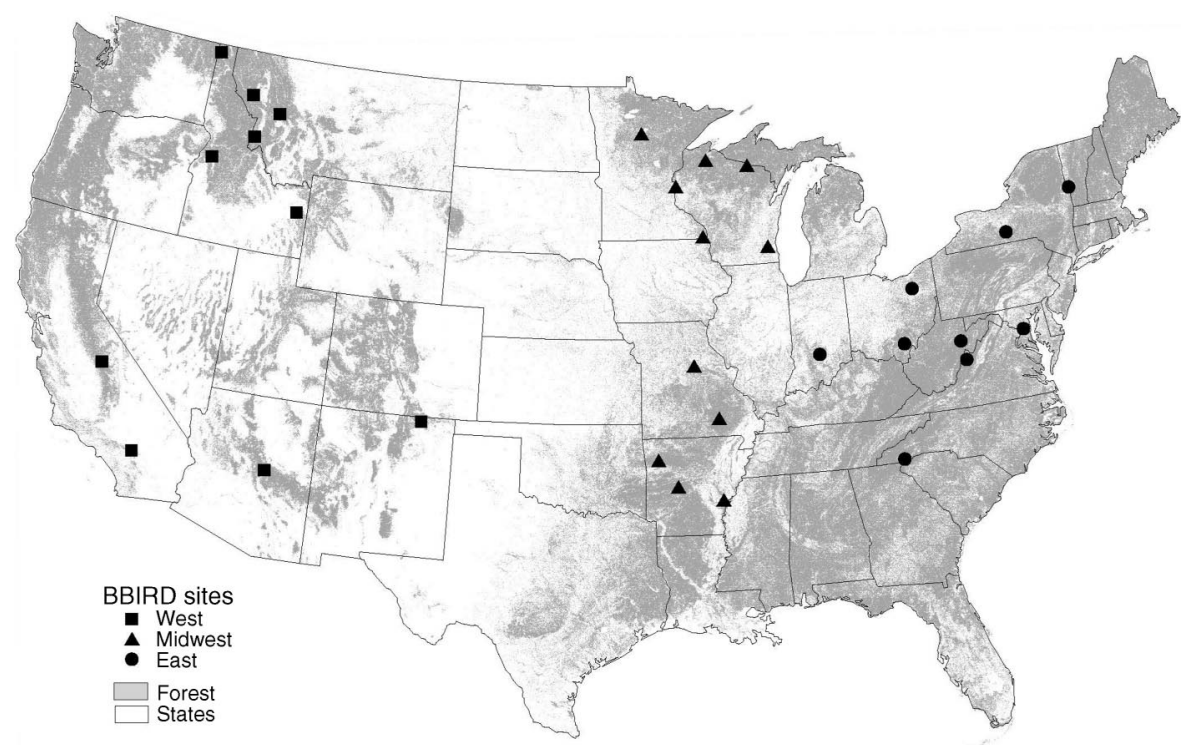

FIG. 1. Distribution of 30 BBIRD sites across the Western, Midwestern, and Eastern biogeographic regions of the United States in relation to forest cover (gray).

or as an historical artifact of past parasite distribution (Thompson et al. 2000).

Broad tests of such scale effects are lacking because of an absence of replicated landscape studies, due to the logistical difficulties of measuring nesting parameters in multiple landscapes. We use a collaborative data set from 404 plots at 30 sites across 17 states of the conterminous United States to assess the effects of fragmentation on nest predation and parasitism across a hierarchy of spatial scales. To test for scale effects, we compared site-specific estimates of nest parasitism and predation for 25 bird species and three nesting guilds (ground, shrub, canopy) relative to digital land cover at three spatial scales: (1) patch: the average distance to the nearest habitat edge; (2) landscape: within 1-100 km radii; and (3) biogeographic: among Eastern, Midwestern, and Western biogeographic regions, and the distance from the center of cowbird abundance in the Midwest. We then generated a predictive model of the relationship between fragmentation and population growth potential to map the latter across the geographic range of the two best-sampled species, the Ovenbird (Seiurus aurocapilla) and the Wood Thrush (Hylocichla mustelina).

\section{Methods}

\section{The nest record database}

The Breeding Biology Research and Monitoring Database (BBIRD) program was initiated in 1992 to implement standardized sampling protocols among researchers to allow replicated examination of breeding performance of nongame birds. For our analyses, we used data on breeding performance (clutch size, nest success, nest predation, and cowbird parasitism) from nest records of birds breeding in forest habitat within 404 plots at 30 sites distributed across the conterminous United States (Fig. 1). Guild-level analyses used data from 23425 nest records of 100 species, whereas species-level analyses used data for up to 25 species with sufficient breeding performance data from $\geq 5$ sites. Within each site, between 1 and 33 plots, each incorporating an area of $\sim 10-50$ ha, were separated by distances of 1-50 km from one another. Study sites were not selected randomly, but analyses indicate that BBIRD plots are representative of available landscapes in the United States (Appendix A). Contributing investigators used the standardized BBIRD protocol (Martin and Guepel 1993; available online) ${ }^{2}$ for collecting nest data. We treated the plots of more than one investigator as a single site if plots were $<50 \mathrm{~km}$ apart.

\section{Characterizing habitat variables}

We selected a suite of habitat metrics that have biological meaning with respect to the hypothesized edge, area, and biogeographic influences on predatorparasite abundance. Habitat metrics were derived from the National Land Cover Dataset (NLCD), derived from early- to mid-1990s Landsat Thematic Mapper satellite data (Vogelmann et al. 2001; available online). ${ }^{3}$ The NLCD recognizes 21 different land cover types mapped at a $30-\mathrm{m}^{2}$ pixel resolution. For our analyses, we grouped certain NLCD land cover types to recognize the following four of principal interest: (1) forest, including deciduous, evergreen and mixed forests, and woody wetlands; (2) grassland, including grassland/herbaceous and pasture/hay; (3) cropland, includ-

\footnotetext{
${ }^{2}\langle$ http://pica.wru.umt.edu/BBIRD $\rangle$

${ }^{3}\langle\mathrm{http}: / /$ landcover.usgs.gov/nationallandcover.html $\rangle$
} 
ing orchards/vineyards/other, row crops, small grains, and fallow; and (4) developed, including grassland and cropland, together with residential and commercial/industrial/transportation. Using ArcInfo (ESRI, Redlands, California, USA) and Apack (University of Wisconsin, Madison, Wisconsin, USA; Mladenoff and DeZonia 2002) software, habitat metrics were extracted at four principal spatial scales: (1) the patch scale, the distance from the plot center to the nearest forest or developed land cover edge, averaged for all plots within each site; (2) the landscape scale (fine), within radii of $1 \mathrm{~km}, 5$ $\mathrm{km}, 10 \mathrm{~km}$, and $20 \mathrm{~km}$ of each study plot center, averaged for all plots within each site; (3) the landscape scale (broad), within radii of $50 \mathrm{~km}$ and $100 \mathrm{~km}$ of each study site center; and (4) the biogeographic scale, the distance from the site center to the nearest edge of the core distribution of cowbirds in the Midwest (mean count $\geq 30$ ), using the North American Breeding Bird Survey (BBS) data from the USGS Patuxent Wildlife Research Center (available online) ${ }^{4}$ The landscapescale habitat features included (1) the percentage cover of each of the four land cover types within each fixed radius, and (2) the percentage of core forest cover, average forest patch size, and forest edge density (edge length per unit area of all forest patches) within each fixed radius. The percentage of land cover was determined from the total land area (i.e., after subtracting the area of all open water) within each fixed radius. Suitable transformations were applied to all variables that were not normally distributed. Site characteristics for selected habitat variables are summarized in Appendix B.

\section{Species-level and nesting guild-level analyses}

Species-level analyses used data on rates of nest predation and brood parasitism experienced by up to 25 species with data from five or more sites, and each of three nesting guilds. A species was assigned to a nesting guild on the basis of the average nest height: within $30 \mathrm{~cm}$ of ground level (ground); 0.3-3 m (shrub); and $>3 \mathrm{~m}$ (canopy). All niche- and cavity-nesting species were excluded. For these analyses, we aggregated data from all plots within sites. Nests were aggregated by species, which were, in turn, aggregated by nesting guild. Sites and species were included in the analyses only if the relevant nesting success data were derived from a sample of five or more nests per site. Thus the ground-, shrub- and canopy-nesting guild analyses incorporated data on 25,39, and 36 species, respectively, for effects on nest predation, and data on 21, 29, and 19 species, respectively, for effects on nest parasitism. The mean number of species included in any guild at a site was 4 (range: 1-14 species). At the guild level, we were interested in how mean nest predation or parasitism on each guild (i.e., averaged across all species in the guild at a site) varied with the extent of frag-

\footnotetext{
${ }^{4}\langle$ http://www.pwrc.usgs.gov/bbs $\rangle$
}

mentation among sites. The species-specific nest parasitism rate was calculated as the proportion of all nesting attempts in which the laying of a cowbird egg or the presence of a cowbird nestling was detected. The guild-specific nest parasitism rate was calculated as the mean parasitism rate among all host species with five or more nests per site. A host species is one recorded as parasitized one or more times in the BBIRD database. The guild-specific nest predation rate was calculated as the mean predation rate among all species with five or more nests per site.

We used analysis of covariance (ANCOVA), using species as a fixed factor and predictor variables as covariates, to explain variation in dependent variables (nest parasitism, daily nest predation, or annual fecundity). In the model selection process for each dependent variable, the predictor variables (indices of fragmentation) at different scales were successively included and excluded from the same nested model. Deviance values were therefore used to select the most parsimonious model (Dobson 2002). After identifying the most appropriate covariate(s), we tested whether relationships with the dependent variable differed among biogeographical regions or nesting guilds using ANCOVA and using region or nesting guild as a fixed factor. All analyses were performed using the General Linear Model (GLM) procedure in SPSS (SPSS, Chicago Illinois, USA).

\section{General assumptions for demographic analyses}

To assess the net consequences of nest parasitism and predation on the annual fecundity of populations, we calculated site-specific annual breeding productivity for 22 species that had estimates of the mean number of young fledged from samples of five or more nests per site from five or more sites. For multibrooded species, the annual production of fledglings per female was calculated from species-specific demographic data (see Appendix C), using the equations of Ricklefs and Bloom (1977), with the following inputs: (1) the length of the laying season ( $L$ days), estimated from the number of nests initiated each week (Ricklefs 1966); (2) the daily nest mortality rate $(m) ;(3)$ the probability (cf. Mayfield 1975) that a nest successfully fledges at least one young $\left(p_{\mathrm{s}}\right)$; (4) the average fledging brood size per successful nest; (5) the delay before a new clutch is laid after nest failure ( $r_{\mathrm{f}}$ days); and (6) the delay before a new clutch is laid after successful fledging ( $r_{\mathrm{s}}$ days). For single-brooded species, the annual production of fledglings per female at each site was calculated using a simple, individual-based model $\left(1 \times 10^{6}\right.$ simulations $)$ with the following rules: (1) all individuals begin laying on day 1 of the laying season $(L)$; (2) nests fail with a probability equal to the site-specific daily mortality rate $(m)$ each day; $(3)$ nests that survive the length of the nesting period fledge the average number of young per successful nest for that site; (4) all individuals whose nests fail re-lay after $r_{\mathrm{f}}$ days, unless the end 
of the laying season $(L)$ has been reached; and (5) all individuals that fledge one nest do not initiate a second brood.

We estimated population growth rate $(\lambda)$ for two bird species that are especially well represented across the landscapes we studied: the Wood Thrush and the Ovenbird. We used the equation: $\lambda=P_{\mathrm{A}}+P_{\mathrm{J}} \beta$, where $P_{\mathrm{A}}$ is the probability of annual adult female survival, $P_{\mathrm{J}}$ is the probability of juvenile female survival from fledging to the following breeding season, and $\beta$ is the production of female fledglings per pair per breeding season (Pulliam 1988). We used 58\% for adult survival for Wood Thrushes, based on results for after-secondyear female Wood Thrushes in Delaware (Roth and Johnson 1993, Brown and Roth 2002), and the same estimate for Wood Thrushes in Georgia, based on a combined mark-recapture and radiotelemetry study (Powell et al. 2000). Ovenbird survival estimates were available only for adult males. We used the mean $(61.5 \%)$ of two survival estimates from Missouri (61\%) (Porneluzi and Faaborg 1999) and contiguous forest in Saskatchewan (62\%) (Bayne and Hobson 2002). We assumed juvenile female survival as $50 \%$ of adult survival, as hypothesized for north-temperate passerines (Greenberg 1980, Temple and Cary 1988). Under these assumptions, annual reproductive output should exceed 2.9 and 2.6 fledged young per female per year for the Wood Thrush and Ovenbird, respectively, to maintain $\lambda \geq 1$.

\section{Fragmentation effects on $\lambda$ and species abundance}

To map the relationship between $\lambda$ of two species (the Ovenbird and the Wood Thrush) and continental patterns of land cover, we first regressed $\lambda$ on the percentage of the landscape in developed land cover within a $10 \mathrm{~km}$ radius (i.e., the primary landscape predictor of annual productivity) for our 30 sites. To extrapolate the observed relationship between $\lambda$ and the level of landscape fragmentation to the continental distributions of the two species, we first used land cover data from NLCD to identify the proportion of developed lands within a $10 \mathrm{~km}$ radius of all forest cells. Using ArcInfo software, we created a grid of developed land cover for the conterminous USA. To make analyses feasible, we then resampled the results to a $1-\mathrm{km}$ resolution using a nearest-neighbor algorithm. A moving window analysis (ArcInfo's FOCALSUM function) was used to count the number of cells of developed land cover within a circle of $10 \mathrm{~km}$ radius, centered on each forest grid cell in turn. For each forest cell, the calculated percentage of developed land cover within the $10 \mathrm{~km}$ radius was converted to a $\lambda$ estimate based on the regression of $\lambda$ on the percentage of the landscape in developed land cover within a $10 \mathrm{~km}$ radius for our 30 sites. Finally, $\lambda$ associated with each forest cell was mapped according to the following categories: strong sinks $(\lambda<0.90)$, weak sinks $(\lambda 0.90-0.99)$, weak sources $(\lambda$ 1.0-1.09), and strong sources $(\lambda>1.1)$.
To relate continental patterns of Ovenbird and Wood Thrush abundance to the extent of landscape fragmentation, we built a database containing (1) abundance estimates for each species per BBS route, averaged over all years and excluding records that had less than five years of counts and records that averaged $<3.5$ birds over all years, and (2) the proportion of developed land cover within a $10 \mathrm{~km}$ radius of each BBS route, averaged for all forest cells on the BBS route, as identified from the BBS routes map layer, spatially matched to our land cover layer. ${ }^{5}$

\section{Sources of uncertainty}

Although we have endeavored to be rigorous in our approach, we acknowledge several sources of uncertainty in our study, including sampling error, high natural variability in nest predation and parasitism, parameter assumptions in the demographic models, and data quality issues, such as measurement and database management error. Sample size of nests from sites for which species-specific predation and parasitism rates were determined ranged from 5 to 1551 , resulting in a wide range in the standard error associated with individual data points used in the regression analyses. Sources of measurement error in nest-fate interpretation were minimized through the use of a standard field protocol and annual meetings with contributors. Other potential sources of measurement error include positional errors in the mapped locations of study plots, variation in the distribution of plots within sites (tightly clustered at some sites, but scattered over many kilometers at others) that affects the representativeness of the site center location, errors in land cover classification and image registration in the NLCD land cover database, and database management errors in the BBIRD, BBS, and NLCD databases.

\section{RESUlts}

Nest parasitism rates among BBIRD sites were strongly correlated with the mean proximity to developed lands at the patch scale (i.e., edge effects) for 17 parasitized species (ANCOVA: edge effect $F_{1,137}=$ 43.4, $P<0.001$; species effect $F_{16,137}=0.17, P=$ $0.005)$. The interaction term in the first step of the ANCOVA was nonsignificant $\left(F_{16,137}=1.5, P=0.13\right)$. Yet nest parasitism was more strongly correlated with land cover indices of forest fragmentation at landscape scales. Land cover at the $20 \mathrm{~km}$ radius scale consistently explained the greatest proportion of variation in nest parasitism (Table 1), and edge or patch effects did not add explanatory power. Instead, nest parasitism increased strongly with the proportion of developed land cover in the $20 \mathrm{~km}$ radius landscape for all 17 parasitized species (ANCOVA: land cover effect $F_{1,121}=$ 171.9, $P<0.001$; species effect $F_{16,121}=1.1, P=0.4$; interaction $F_{16,121}=3.5, P<0.001$ ) and three nesting

\footnotetext{
${ }^{5}\langle$ http://nationalatlas.gov/birdm.html $\rangle$
} 
TABLE 1. Percentage variance (adjusted $R^{2}$ values) in nest parasitism rate, daily nest predation rate, or annual fecundity among sites explained by each predictor variable when used alone as a covariate to the dependent variable in a univariate ANCOVA, with species used as a fixed factor.

\begin{tabular}{|c|c|c|c|c|c|c|c|c|}
\hline \multirow[b]{2}{*}{ Covariate scale } & \multirow[b]{2}{*}{ To edge } & \multicolumn{4}{|c|}{ Land cover percentage } & \multirow{2}{*}{$\begin{array}{l}\text { Mean patch } \\
\text { size }\end{array}$} & \multirow{2}{*}{$\begin{array}{l}\text { Edge } \\
\text { density }\end{array}$} & \multirow{2}{*}{$\begin{array}{c}\text { Core forest, } \\
\%\end{array}$} \\
\hline & & Forest & Cropland & Grassland & Developed & & & \\
\hline \multicolumn{9}{|l|}{ Nest parasitism rate } \\
\hline Patch & $27.2 \dagger$ & & & & & & & \\
\hline $1 \mathrm{~km}$ & & 30.6 & 21.2 & 36.4 & 38.6 & 30.9 & 29.6 & 34.3 \\
\hline $5 \mathrm{~km}$ & & 48.0 & 31.3 & 50.3 & 52.7 & 53.1 & 43.2 & 46.4 \\
\hline $10 \mathrm{~km}$ & & 51.3 & 31.2 & 48.7 & 54.7 & 54.1 & 45.5 & 48.4 \\
\hline $20 \mathrm{~km}$ & & 54.1 & 31.0 & 50.0 & 55.8 & & & \\
\hline $50 \mathrm{~km}$ & & 47.3 & 29.6 & 37.2 & 48.1 & 45.5 & & 45.4 \\
\hline $100 \mathrm{~km}$ & & 38.0 & 25.5 & 34.1 & 43.3 & 36.5 & & 39.4 \\
\hline Biogeographic & $0.7 \ddagger$ & & & & & & & \\
\hline \multicolumn{9}{|c|}{ Daily nest predation rate } \\
\hline Patch & $19.5 \dagger$ & & & & & & & \\
\hline $1 \mathrm{~km}$ & & 19.3 & $21.3^{*}$ & 19.4 & 19.4 & 19.3 & 19.2 & 19.5 \\
\hline $5 \mathrm{~km}$ & & 19.7 & $21.5^{*}$ & 19.3 & 19.8 & 20.1 & 19.6 & 20.0 \\
\hline $10 \mathrm{~km}$ & & 19.9 & $21.4 *$ & 19.3 & 19.9 & 20.1 & 19.9 & 20.3 \\
\hline $20 \mathrm{~km}$ & & 20.0 & $21.5^{*}$ & 19.2 & 20.1 & & & \\
\hline $50 \mathrm{~km}$ & & 20.1 & $21.4^{*}$ & 19.2 & 20.2 & 20.2 & & $21.3^{*}$ \\
\hline $100 \mathrm{~km}$ & & 20.2 & $21.7 *$ & 19.3 & 19.8 & 20.2 & & $21.3^{*}$ \\
\hline \multicolumn{9}{|l|}{ Annual fecundity } \\
\hline Patch & $46.7 \dagger$ & & & & & & & \\
\hline $1 \mathrm{~km}$ & & 46.9 & 48.4 & 45.0 & 50.0 & 46.8 & 46.3 & 47.6 \\
\hline $5 \mathrm{~km}$ & & 52.1 & 49.6 & 48.1 & 54.5 & 53.0 & 50.9 & 51.0 \\
\hline $10 \mathrm{~km}$ & & 53.4 & 49.4 & 47.6 & 55.2 & 54.0 & 51.9 & 52.0 \\
\hline $20 \mathrm{~km}$ & & 52.8 & 48.9 & 47.0 & 54.0 & & & \\
\hline $50 \mathrm{~km}$ & & 50.0 & 47.0 & 43.5 & 50.2 & 51.2 & & 50.1 \\
\hline $100 \mathrm{~km}$ & & 47.5 & 45.1 & 42.3 & 46.9 & 48.5 & & 48.1 \\
\hline
\end{tabular}

Note: Deviance criteria established that single-parameter models were most parsimonious in all cases. For ease of interpretation, we use $R^{2}$ values to compare among predictor variables and scales. ANCOVAs for nest parasitism rate, daily nest predation rate, and annual fecundity used data for 17, 25, and 22 species, respectively. For nest parasitism rate and annual fecundity, all ANCOVA $P<0.001$, except at the biogeographic scale, where $P=0.3$. For daily nest predation rate, statistical significance is indicated by asterisks: $* P<0.05$.

$\dagger$ The variable is the average distance between plot centers and nearest developed land cover edge.

$\ddagger$ The variable is the distance to nearest edge of Brown-headed Cowbird core distribution in the Midwest.

guilds (Fig. 2). However, parasitism probability was not related to distance from the biogeographic center of cowbird abundance while controlling for variation in landscape fragmentation $\left(F_{1,120}=0.11, P=0.7\right)$. Furthermore, the relationship between nest parasitism and landscape-level fragmentation did not differ between major biogeographic (i.e., Western, Midwestern, and Eastern) regions of the United States (ANCOVA: $P>0.2$ for all three nesting guilds).

The daily nest predation rate was not related to the distance from the nearest developed land cover edge among 25 species (ANCOVA: edge effect $F_{1,162}=2.4$, $P=0.13$; species effect $F_{24,162}=2.2, P=0.002$; interaction $\left.F_{24,162}=2.0, P=0.006\right)$. In the guild-level analyses, using biogeographic region as a fixed factor, daily nest predation was not related to the distance from nearest developed land cover edge for either the canopy-nesting (ANCOVA: edge effect $F_{1,22}=0.75, P=$ 0.4 ; region effect $F_{2,22}=7.83, P=0.003$; interaction $F_{2,22}=4.71, P=0.020$ ) or shrub-nesting guilds (ANCOVA: edge effect $F_{1,22}=0.05, P=0.8$; region effect $F_{2,22}=2.12, P=0.14$; nonsignificant interaction). However, nest predation was correlated with an edge effect in the ground-nesting guild, a relationship that did not differ among biogeographic regions (ANCOVA: edge effect $F_{1,19}=7.16, P=0.015$; region effect $F_{2,19}=0.88, P=0.4$; nonsignificant interaction) (Fig. $3)$. On the other hand, edge effects did vary biogeographically; daily nest predation decreased with increasing distance from the nearest developed land cover edge for all nesting guilds within the Eastern region alone (ANCOVA: edge effect $F_{1,23}=13.54, P=0.001$; guild effect $F_{2,23}=1.48, P=0.2$; nonsignificant interaction)

The daily nest predation rate was significantly correlated with the proportion of the landscape $(10 \mathrm{~km}$ radius) in developed land cover for 25 species (ANCOVA: land cover effect $F_{1,162}=4.55, P=0.034$; species effect $F_{24,162}=1.97, P=0.007$; interaction $F_{24,162}=1.68, P=0.032$ ). However, in the guild-level analyses, using biogeographic region as a fixed factor, nest predation was not related to developed land cover for the canopy-nesting (ANCOVA: land cover effect $F_{1,22}=0.07, P=0.8$; region effect $F_{2,22}=2.16, P=$ 0.14 ; nonsignificant interaction), shrub-nesting (ANCOVA: land cover effect $F_{1,24}=1.45, P=0.24$; region effect $F_{2,24}=3.32, P=0.054$; nonsignificant interaction), or ground-nesting guilds (ANCOVA: land cov- 


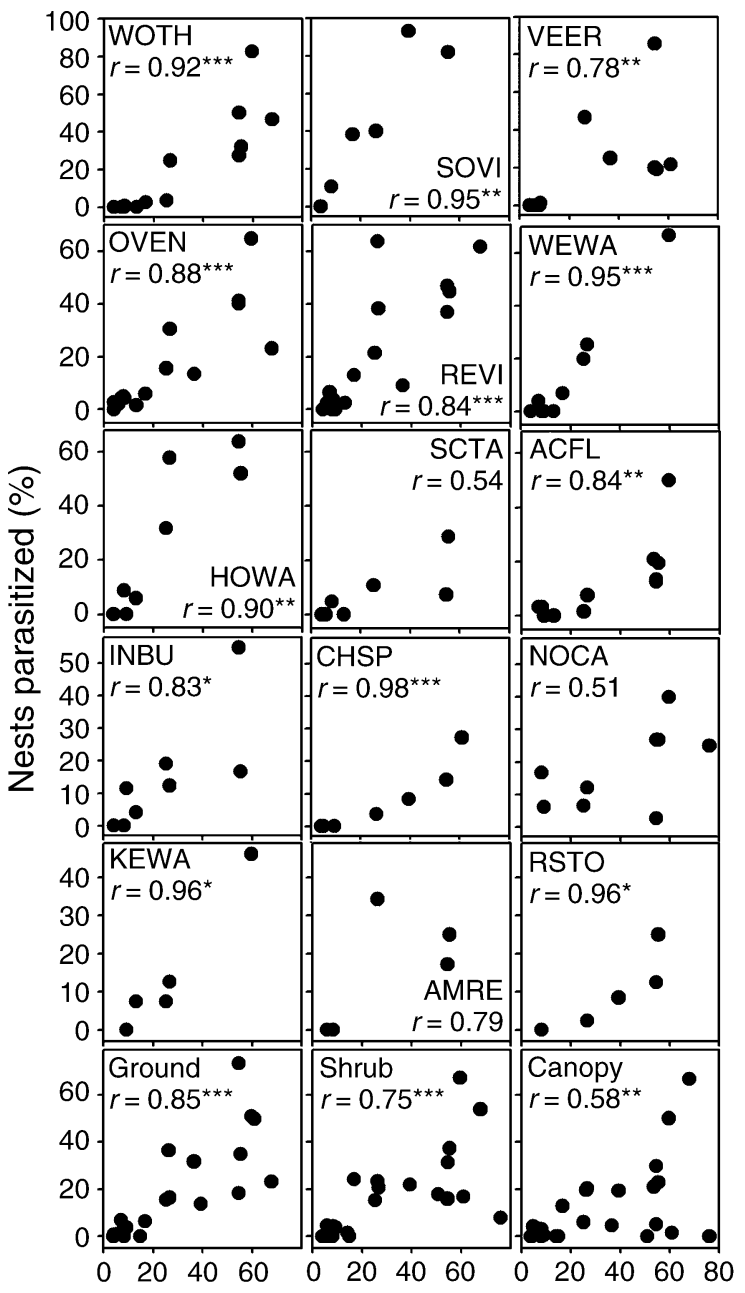

Developed land cover within $20 \mathrm{~km}$ radius (\%)

FIG. 2. Nest parasitism by the Brown-headed Cowbird increases with the percent cover of developed land within a $20 \mathrm{~km}$ radius of 30 sites in the United States, for each of 17 species (15 illustrated; five species were excluded because they are not parasitized) and three nesting guilds (combined probabilities test $P<0.001$ ). Significance of $r$, individual correlation coefficient (after data were arcsine-transformed) is indicated as: $* P<0.05$; $* * P<0.01$; $* * * P<0.001$. Land cover data represent averages for all plots within each site. Species are ACFL, Acadian Flycatcher; AMRE, American Redstart; CHSP, Chipping Sparrow; HOWA, Hooded Warbler; INBU, Indigo Bunting; KEWA, Kentucky Warbler; NOCA, Northern Cardinal; OVEN, Ovenbird; REVI, Redeyed Vireo; RSTO, Rufous-sided Towhee complex; SCTA, Scarlet Tanager; SOVI, Solitary Vireo complex; VEER, Veery; WEWA, Worm-eating Warbler; WOTH, Wood Thrush.

er effect $F_{1,19}=0.95, P=0.3$; region effect $F_{2,19}=$ $0.45, P=0.6$; nonsignificant interaction). Nonetheless, controlling for distance to the nearest developed land cover edge, daily nest predation increased with the proportion of the landscape in developed land cover across nesting guilds (ANCOVA: land cover effect $F_{1,72}=$ 4.18, $P=0.045$; edge effect $F_{1,72}=2.64, P=0.11$; guild effect $F_{2,72}=1.23, P=0.3$ ).
Annual fecundity was most strongly, and negatively, correlated with the proportion of developed land cover in the landscape at the $10 \mathrm{~km}$ radius scale (Table 1, Fig. 4). The Gray Catbird (Dumetella carolinensis) and Chipping Sparrow (Spizella passerina), which prefer shrubby (i.e., disturbed) habitats, were the only 2 of 22 species that exhibited a positive (but nonsignificant) relationship (Fig. 4). Under the assumption of equal adult and juvenile survival rates among sites, the population growth rate $(\lambda)$ is directly proportional to annual fecundity. The particularly strong relationship between $\lambda$ and developed land cover at landscape scales allows us to predict spatial variation in population growth potential across the geographic range of a species. The population growth rate $(\lambda)$ was predicted from the regression of $\lambda$ on the proportion of developed land cover (arcsine-transformed) within a $10 \mathrm{~km}$ radius $(x)$, using the relationship $\lambda=-0.292 x+1.224(F=17.5$, $\left.P=0.001, R^{2}=0.54\right)$ for the Ovenbird, and $\lambda=$ $-0.291 x+1.098\left(F=26.4, P<0.001, R^{2}=0.68\right)$ for the Wood Thrush (Fig. 5).

Relating BBS abundance estimates to the proportion of developed land cover within a $10 \mathrm{~km}$ radius of BBS routes, we found that Ovenbird abundance decreases strongly with increasing developed land cover in the landscape $(r=-0.41, P<0.001, n=609)$, whereas

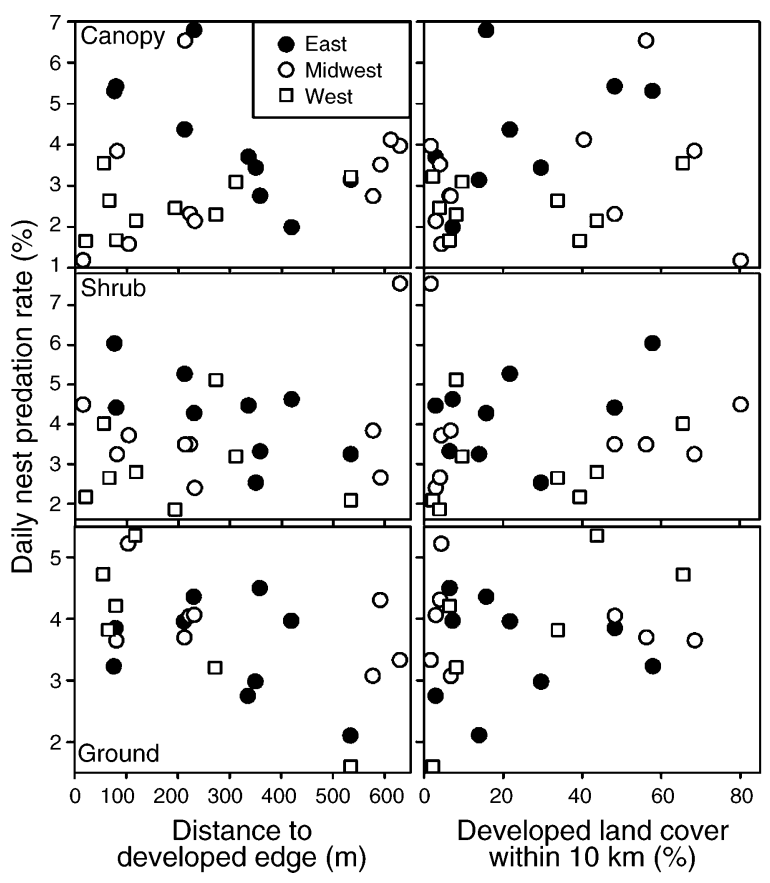

FIG. 3. Daily nest predation rate in relation to distance to the nearest developed land cover edge (left-hand panels) and the percentage of the landscape (within a $10-\mathrm{km}$ radius of sites) in developed land cover (right-hand panels) for each of the canopy-, shrub- and ground-nesting guilds. Data are from 30 sites in the Western, Midwestern, and Eastern biogeographic regions of the United States. Each datum point represents the daily predation rate average for all species with five or more nests from each site. 


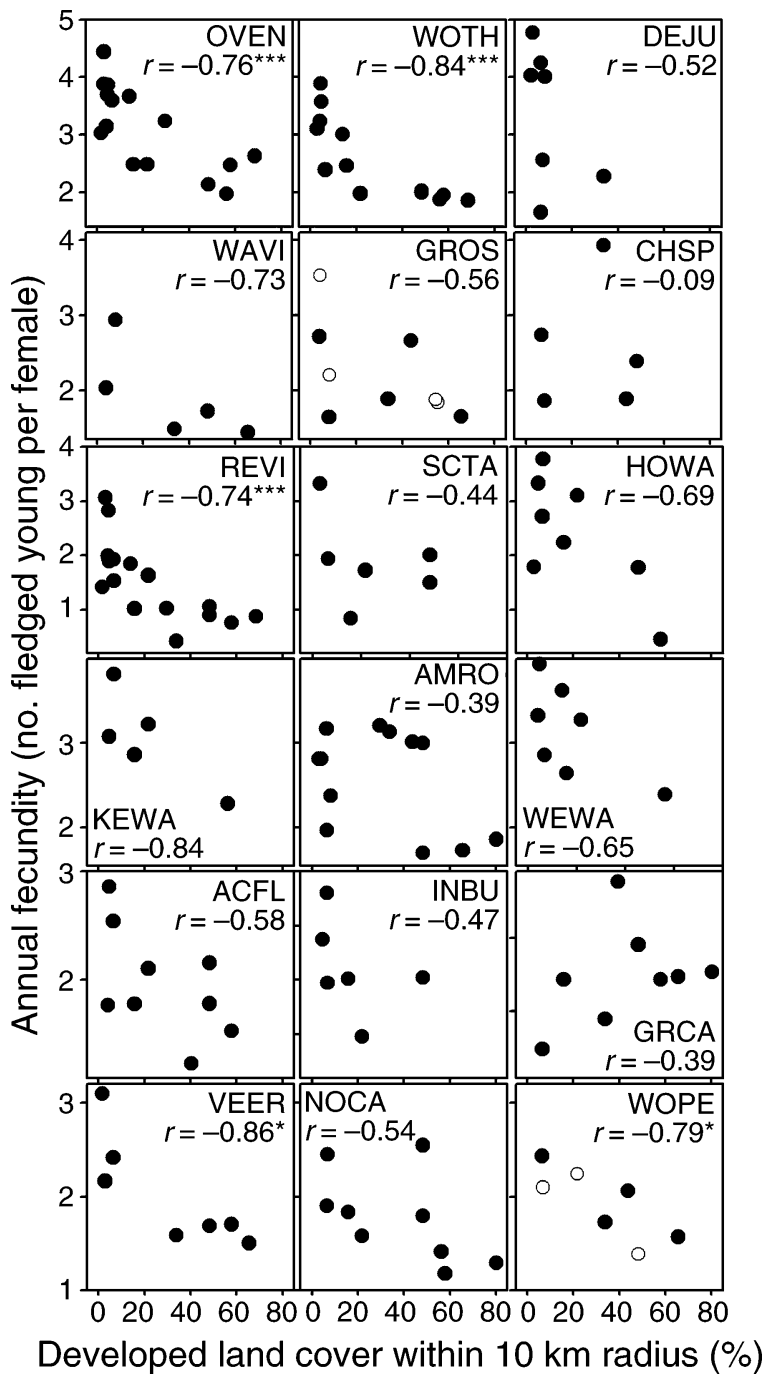

FIG. 4. Annual fecundity decreases with an increase in developed land cover within a $10 \mathrm{~km}$ radius of sites (average for all plots within each site) for 22 species or species groups (18 illustrated) overall (ANCOVA: land cover effect, $F_{1,152}$ $=54, P<0.001$; species effect, $F_{21,152}=8.4, P<0.001$; nonsignificant interaction). Significance of $r$, individual correlation coefficient (after data were arcsine-transformed) is indicated as: $* P<0.05 ; * * P<0.01$. Species: AMRO, American Robin; DEJU, Dark-eyed Junco; GRCA, Gray Catbird; GROS, Black-headed (closed circles) and Rose-breasted (open circles) Grosbeak; WOPE, Western (closed circles) and Eastern (open circles) Wood-Pewee. Other abbreviations are as in Fig. 1.

Wood Thrush abundance decreases weakly $(r=-0.10$, $P=0.005, n=861)$.

\section{DISCUSSION}

\section{Fragmentation effects on nest parasitism}

Brown-headed Cowbirds forage in open, shortgrass habitats, particularly agricultural and other humanmodified habitats, but can commute up to $15 \mathrm{~km}$ to parasitize hosts breeding in forests (Lowther 1993,
Curson et al. 2000). Consequently, parasitism is expected to increase in forest that is closer to cowbird feeding habitat, such as developed land (Tewksbury et al. 1999). Our results support this predicted edge effect; parasitism rates correlated positively with average proximity to developed lands at the patch scale (Table 1). Parasitism risk also can be influenced by the abundance of cowbirds as parasites, which is predicted to increase with the total area of feeding habitat available in the broader landscape (Donovan et al. 1997, Tewksbury et al. 1999, Thompson et al. 2000). Indeed, we found that the $20 \mathrm{~km}$ radius scale consistently explained the greatest proportion of variation in nest parasitism (Table 1). Thus nest parasitism increased strongly with the proportion of developed land cover in the $20 \mathrm{~km}$ radius landscape for all 17 parasitized species and three nesting guilds (Fig. 2). These results support suggestions that landscape area effects of fragmentation can overwhelm edge effects (Thompson et al. 2002).

Historically, Brown-headed Cowbirds were originally concentrated in the Great Plains of central North America, but spread eastward and westward with agricultural development during the 19th and 20th centuries (Mayfield 1965, Rothstein 1994). At a coarse biogeographic scale, the current abundance of cowbirds reflects this historical distribution; cowbird abundance is greatest within the Great Plains and becomes progressively less toward the eastern and western edges of their range (Peterjohn et al. 2000). This pattern of abundance suggests that a biogeographic-scale effect (the distance from the center of cowbird abundance in the Great Plains) may constrain landscape-scale area effects of fragmentation on nest parasitism (Thompson et al. 2000). However, we found no support for biogeographic-scale effects. Parasitism probability was not related to the distance from the biogeographic center of cowbird abundance, while controlling for variation in landscape fragmentation. Furthermore the relationship between nest parasitism and landscape-level fragmentation did not differ between major biogeographic regions (i.e., Western, Midwestern, and Eastern) of the United States (Fig. 2). Thus local landscape conditions appear to be more important in influencing cowbird abundance and parasitism risk than do biogeographic effects. This reinforces the importance of local management action.

\section{Fragmentation effects on nest predation}

Habitat fragmentation also is thought to increase the risk of nest predation (Wilcove 1985), especially from edge effects (Donovan et al. 1997, Chalfoun et al. 2002). However, we found mixed results. Comparing nesting guilds, we found evidence of an edge effect on nest predation for the ground-nesting guild, but not for the shrub-nesting or canopy-nesting guilds (Fig. 3). Also, edge effects varied biogeographically; daily nest predation decreased with increasing distance from the 


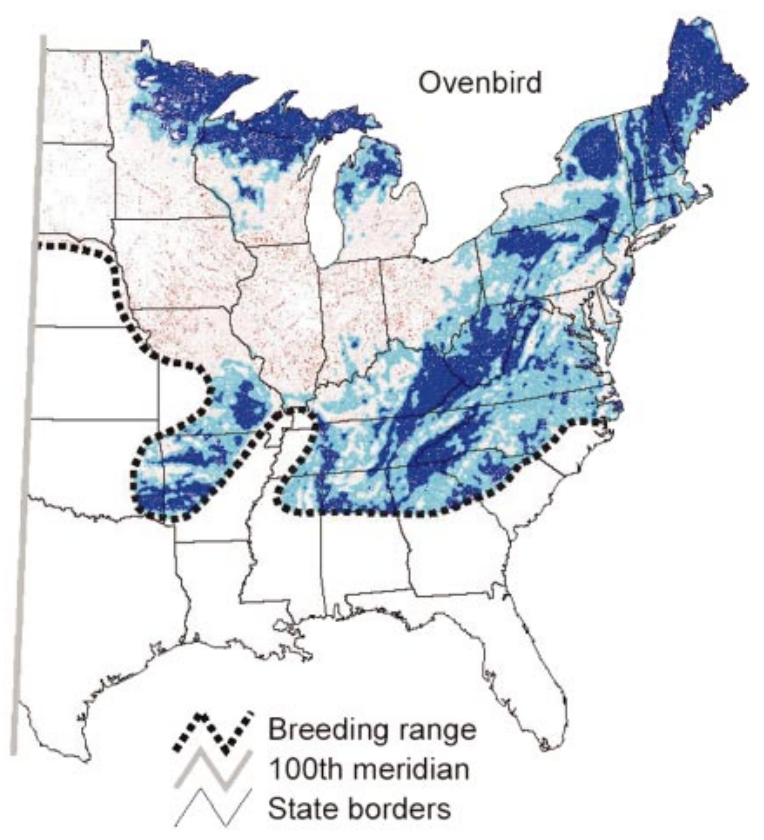

\begin{tabular}{ll}
\multicolumn{1}{l}{$\lambda$} & $<0.9$ \\
& $0.9-1$ \\
& $1-1.1$ \\
\hline \hline & $>1.1$ \\
\hline & Nonforest habitat
\end{tabular}

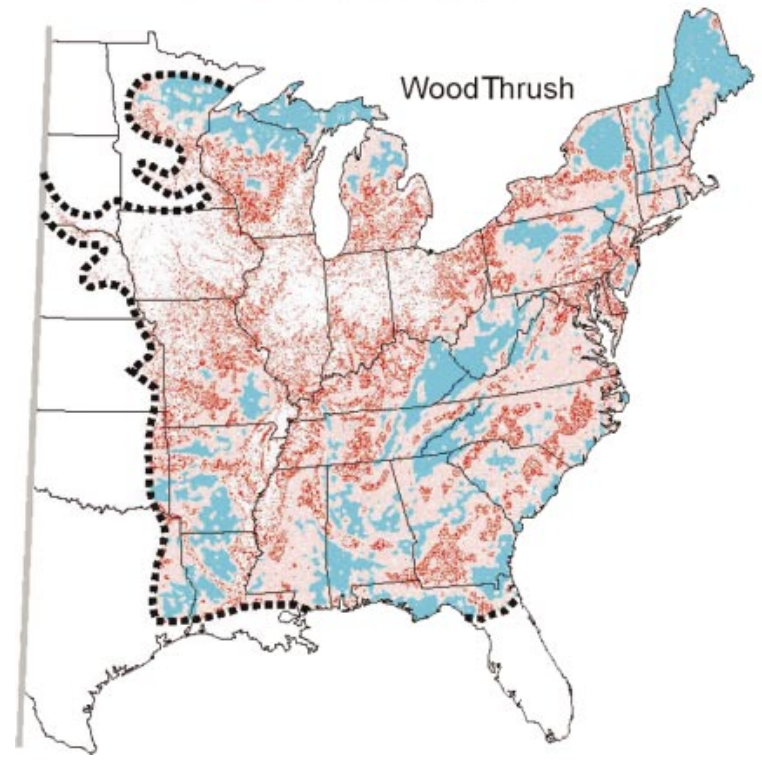

FIG. 5. Predicted population growth rate $(\lambda)$ of Ovenbird (top) and Wood Thrush (bottom) in relation to forest cover (colored cells) east of the 100th meridian. Note that sink habitats are more prevalent for the Wood Thrush $(80 \%$ of forest cover classified as sink), whereas source habitats are more prevalent for the Ovenbird ( $72 \%$ of forest cover classified as source). nearest developed land cover edge for all nesting guilds within the Eastern region alone (Fig. 3). Our detection of weak edge effects may reflect the scale of our analyses relative to the scale at which predators may be responding; our data include nests aggregated across plots (commonly 40 ha in size) within each site and can include nests at a broad range of distances from an edge, which might influence predation responses (Burke and Nol 2000, Flaspohler et al. 2001). Nonetheless our detection of increased nest predation closer to forest edges for ground-nesting species (Fig. 2) supports previous suggestions (Chalfoun et al. 2002) that edge effects are strongest for ground-nesting species.

In agreement with compelling experimental (Donovan et al. 1997), and other correlative evidence (Robinson et al. 1995, Chalfoun et al. 2002, Thompson et al. 2002), our data provide further support for the idea that nest predation increases with forest fragmentation at landscape scales. In particular, after controlling for distance to the nearest developed land cover edge, nest predation across all nesting guilds increased with the proportion of the landscape in developed land cover within a $10 \mathrm{~km}$ radius of BBIRD sites.

\section{Fragmentation effects on population growth potential}

Nest predation and brood parasitism exert the largest impacts on annual fecundity (number of young fledged per female per year) of bird populations (Martin 1992). Our extensively replicated studies allow us to use observed relationships to predict effects of fragmentation on annual fecundity across broad spatial scales for the first time. The strong relationships we found between annual fecundity and developed land cover (Fig. 4) can be used to examine spatial variation in population growth potential across the geographic ranges of species to identify source and sink habitats that are critical to population trajectories and priorities for conservation action. Estimates of population growth rate $(\lambda)$ depend critically on the accuracy of assumptions of annual fecundity and both adult and juvenile survival rates. Our estimates of Wood Thrush annual fecundity among BBIRD sites ranged from 1.6 fledged young per female (at a site with $83 \%$ parasitism and $60 \%$ nest failure) to 3.9 fledged young per female. These are within the range of field estimates of Wood Thrush annual fecundity: 2.6 fledged young per female (range 1.7-3.8) over the period 1974-1990 in a 15-ha Delaware forest fragment (Roth and Johnson 1993); 0.32.1 fledged young per female at a site with 75-95\% parasitism and 50-80\% nest failure (Trine 1998); and 1.8 fledged young per female at a site with $90 \%$ parasitism and 58\% nest failure (Fauth 2000). Similarly, using nest success data from a published study (Porneluzi and Faaborg 1999) as inputs to our Ovenbird fecundity model yielded a model estimate of annual fecundity (2.98 fledged young per female) that was similar to the field estimate (2.94 fledged young per female) from the same study (Porneluzi and Faaborg 
1999). Thus our fecundity models exhibit adequate performance. Population growth rate estimates are particularly sensitive to adult and juvenile survival rate assumptions (Pulliam 1988). Although we have based our assumptions on the best available data, considerable uncertainty, particularly in juvenile survival, means that our analyses of relative source-sink dynamics (e.g., Fig. 5) should be regarded as works in progress.

Our extrapolation of the relationship between population growth rate $(\lambda)$ and the extent of fragmentation at a landscape scale for two species (Fig. 5) demonstrates two important points. First, sink habitat is more prevalent for Wood Thrushes and source habitat is more prevalent for Ovenbirds (Fig. 5). These results accord well with broad population trends; the more prevalent sink habitat for Wood Thrushes fits with their longterm and broad-scale population declines since 1966 (Roth et al. 1996, Sauer et al. 2003), whereas the more prevalent source habitat for Ovenbirds meshes with their long-term and broad-scale stable or increasing populations (Van Horn and Donovan 1994, Sauer et al. 2003). Thus the relative frequency of source vs. sink habitats provides reasonable indicators of overall population health. For the Wood Thrush, population health may be independently influenced by the loss of breeding habitat following the maturation of eastern forests (Holmes and Sherry 2001). Second, the results identify important areas for conservation, suggesting that (1) extensively forested landscapes in the Ozarks, the Appalachians, New England, northeastern Minnesota, and northwestern Michigan are important source areas that should be preserved; (2) the fragmented forests of the central Midwest are central sink areas where management action may be futile unless it addresses the broadscale influences of forest fragmentation on breeding productivity; and (3) many other areas across the range of each species include a complex mosaic of source and sink areas, where management action could help tip the balance in source-sink dynamics. A primary management objective in these latter areas should be to improve the integrity of the larger forest tracts to ensure that the percentage of forest cover within a 10 $\mathrm{km}$ radius of focal sites is maintained at $>50 \%$ for the Ovenbird, and $>80 \%$ for the Wood Thrush (the minimum requirements for positive population growth). Given the severe effect of cowbird parasitism on host breeding productivity, local-scale interventions can improve forest integrity by minimizing the availability of cowbird feeding habitat within or adjoining (within 10 $\mathrm{km}$ ) forests of particular concern. Cowbirds are particularly attracted to livestock grazing lands, croplands, and human dwellings (Tewksbury et al. 1999, Thompson et al. 2000).

The extent to which a species chooses or avoids landscapes in which its fecundity is high or low can further influence the population impacts of landscape alteration (Donovan and Lamberson 2001). When we related continental patterns of Ovenbird and Wood
Thrush abundance (using BBS data) to the average proportion of developed land cover in landscapes, we found that Ovenbirds strongly avoided fragmented landscapes with a high proportion of developed land cover, where fecundity is low (Fig. 3). Although considerable uncertainties exist with BBS data (Bart et al. 1995, Keller and Scallan 1999), other studies report strong avoidance of edge habitat and fragmented landscapes by Ovenbird females (Gibbs and Faaborg 1990, Villard et al. 1993, Van Horn et al. 1995, Bayne and Hobson 2001). This behavior minimizes the impact of fragmented landscapes on populations and helps to explain stable and increasing Ovenbird populations. In contrast, Wood Thrushes only weakly avoided fragmented landscapes, with only $1 \%$ of the variation in Wood Thrush abundance being associated with landscape fragmentation. Thus the Wood Thrush is less averse to occupying fragmented landscapes where fecundity is low (Fig. 3), thereby increasing the impact of fragmentation and reinforcing the negative population trajectory.

Our approach demonstrates great promise for identifying the appropriate spatial scales and landscape features that influence ecological processes (nest predation and parasitism). Modeling their net consequences for population growth potential allows predictions of overall and spatially explicit population vulnerabilities for conservation action. This facilitates identification of critical areas for preservation, as well as areas that can benefit from management action vs. those areas that may be beyond most practical forms of intervention. Finally, this approach could be strengthened further with spatially explicit information on breeding density, dispersal, and adult and juvenile survival that can be modeled with our spatially explicit information on ecological processes and reproductive success to predict regional population trends.

\section{ACKNOWLEDGMENTS}

We are grateful to all contributors to the BBIRD database, including D. Andersen, V. Artman, J. Bart, J. Bednarz, J. Collazo, R. Cooper, D. Curson, J. DeCecco, R. Dettmers, T. Donovan, T. Edwards, D. Evans Mack, J. Faaborg, D. Flaspohler, S. and L. Garner, G. Geupel, S. Hejl, M. Knutson, B. Logan, M. McFadzen, N. Mathews, V. Piaskowski, L. Petit, P. Porneluzi, K. Purcell, C. Rimmer, C. Smith, J. Tewksbury, D. Whitehead, C. Willis, D. Winslow, and P. Wood. For advice and assistance, we thank R. Bassar, M. Clark, B. DeZonia, W. Hochachka, L. Jette, S. Mason, J. Schumacher, and C. Winne. We thank J. Faaborg and an anonymous reviewer for suggestions that improved the manuscript. This study was funded by grants from the National Center for Environmental Research (NCER) STAR Program, the EPA (R 827673-010 ), the USGS BRD Global Change Program, and the USDA Forest Service.

\section{Literature Cited}

Bart, J., M. Hofschen, and B. G. Peterjohn. 1995. Reliability of the Breeding Bird Survey: effects of restricting surveys to roads. Auk 112:758-761.

Batáry, P., and A. Báldi. 2004. Evidence of an edge effect on avian nest success. Conservation Biology 18:389-400. 
Bayne, E. M., and K. A. Hobson. 2001. Effects of habitat fragmentation on pairing success of ovenbirds: importance of male age and floater behavior. Auk 118:380-388.

Bayne, E. M., and K. A. Hobson. 2002. Apparent survival of male Ovenbirds in fragmented and forested boreal landscapes. Ecology 83:1307-1316.

Brown, W. P., and R. R. Roth. 2002. Temporal patterns of fitness and survival in the Wood Thrush. Ecology 83:958969.

Burke, D. M., and E. Nol. 2000. Landscape and fragment size effects on reproductive success of forest-breeding birds in Ontario. Ecological Applications 10:1749-1761.

Chalfoun, A. D., F. R. Thompson,III, and M. J. Ratnaswamy. 2002. Nest predators and fragmentation: a review and meta-analysis. Conservation Biology 16:306-318.

Curson, D. R., C. B. Goguen, and N. E. Mathews. 2000. Long-distance commuting by Brown-headed Cowbirds in New Mexico. Auk 117:795-799.

Dobson, A. J. 2002. An introduction to generalized linear models. Chapman and Hall, London, UK.

Donovan, T. M., P. W. Jones, E. M. Annand, and F. R. Thompson,III. 1997. Variation in local-scale edge effects: mechanisms and landscape context. Ecology 78:2064-2075.

Donovan, T. M., and R. H. Lamberson. 2001. Area-sensitive distributions counteract negative effects of habitat fragmentation on breeding birds. Ecology 82:1170-1179.

Donovan, T. M., R. H. Lamberson, A. Kimber, F. R. Thompson,III, and J. Faaborg. 1995. Modeling the effects of habitat fragmentation on source and sink demography of Neotropical migrant birds. Conservation Biology 9:1396-1407.

Fauth, P. T. 2000. Reproductive success of Wood Thrushes in forest fragments in northern Indiana. Auk 117:194-204.

Flaspohler, D. J., S. A. Temple, and R. N. Rosenfield. 2001. Species-specific edge-effects on nest success and breeding bird density in a forested landscape. Ecological Applications 11:32-46.

Gibbs, J. P., and J. Faaborg. 1990. Estimating the viability of Ovenbird and Kentucky Warbler populations in forest fragments. Conservation Biology 4:193-196.

Greenberg, R. 1980. Demographic aspects of long distance migration. Pages 493-504 in A. Keast and E. S. Morton, editors. Migrant birds in the Neotropics: ecology, behaviour, distribution, and conservation. Smithsonian Institution Press, Washington, D.C., USA.

Groom, M. J., and N. Schumaker. 1993. Evaluating landscape change: the dimensions of deforestation and habitat fragmentation. Pages 24-44 in P. M. Karieva, J. G. Kingsolver, and R. B. Huey, editors. Biotic interactions and global change. Sinauer, Sunderland, Massachusetts, USA.

Holmes, R. T., and T. S. Sherry. 2001. Thirty-year population trends in an unfragmented temperate deciduous forest: importance of habitat change. Auk 118:589-609.

Keller, C. M. E., and J. T. Scallan. 1999. Potential roadside biases due to habitat changes along Breeding Bird Survey routes. Condor 101:50-57.

Lawton, J. H. 1995. Population dynamic principles. Pages 147-163 in J. H. Lawton and R. May, editors. Extinction rates. Oxford University Press, New York, New York, USA.

Lowther, P. E. 1993. Brown-headed Cowbird (Molothrus ater). In A. Poole and F. Gill, editors. The birds of North America, Number 47. Academy of Natural Sciences, Philadelphia, Pennsylvania, USA, and American Ornithologists' Union, Washington, D.C., USA.

Martin, T. E. 1992. Breeding productivity considerations: what are the appropriate habitat features for management? Pages 455-473 in J. M. Hagan and D. W. Johnston, editors. Ecology and conservation of Neotropical migrants. Smithsonian Institution Press, Washington, D.C., USA.

Martin, T. E., and G. E. Geupel. 1993. Nest-monitoring plots: methods for locating nests and monitoring success. Journal of Field Ornithology 64:507-519.
Mayfield, H. 1965. The Brown-headed Cowbird with old and new hosts. Living Bird 4:13-28.

Mayfield, H. 1975. Suggestions for calculating nesting success. Wilson Bulletin 73:255-261.

Mladenoff, D. J., and B. DeZonia. 2002. APACK 2.22 Analysis Software Users Guide. Department of Forest Ecology and Management, University of Wisconsin, Madison, Wisconsin, USA. 〈http://flel.forest.wisc.edu〉

Peterjohn, B. G., J. R. Sauer, and S. Schwarz. 2000. Temporal and geographic patterns in population trends of Brownheaded Cowbirds. Pages 21-34 in J. N. M. Smith, T. Cook, S. I. Rothstein, S. K. Robinson, and S. G. Sealy, editors. Ecology and management of cowbirds and their hosts. University of Texas Press, Austin, Texas, USA.

Porneluzi, P. A., and J. Faaborg. 1999. Season-long fecundity, survival, and viability of Ovenbirds in fragmented and unfragmented landscapes. Conservation Biology 13:11511161.

Powell, L. A., M. J. Conroy, J. E. Hines, J. D. Nichols, and D. G. Krementz. 2000. Simultaneous use of mark-recapture and radiotelemetry to estimate survival, movement, and capture rates. Journal of Wildlife Management 64:302-313.

Pulliam, H. R. 1988. Sources, sinks, and population regulation. American Naturalist 132:652-661.

Ricklefs, R. E. 1966. The temporal component of diversity among species of birds. Evolution 20:235-242.

Ricklefs, R. E., and G. Bloom. 1977. Components of avian breeding productivity. Auk 94:86-96.

Robbins, C. S., J. R. Sauer, R. S. Greenberg, and S. Droege. 1989. Population declines in North American birds that migrate to the Neotropics. Proceedings of the National Academy of Science, USA 86:7658-7662.

Robinson, S. K., F. R. Thompson,III, T. M. Donovan, D. R. Whitehead, and J. Faaborg. 1995. Regional forest fragmentation and the nesting success of migratory birds. Science 267:1987-1990.

Roth, R. R., and M. S. Johnson. 1993. Long-term dynamics of a Wood Thrush population breeding in a forest fragment. Auk 110:37-48.

Roth, R. R., M. S. Johnson, and T. J. Underwood. 1996. Wood Thrush (Hylocichla mustelina). In A. Poole and F. Gill, editors. Birds of North America, Number 246. Academy of Natural Sciences, Philadelphia, Pennsylvania, USA, and American Ornithologists' Union, Washington, D.C., USA.

Rothstein, S. I. 1994. The cowbird's invasion of the far west: history, causes, and consequences experienced by host species. Studies in Avian Biology 15:301-315.

Sauer, J. R., J. E. Hines, and J. Fallon. 2003. The North American breeding bird survey, results and analysis 19662003. USGS Patuxent Wildlife Research Center, Laurel, Maryland, USA.

Stephens, S. E., D. N. Koons, J. J. Rotella, and D. W. Willey. 2003. Effects of habitat fragmentation on avian nesting success: a review of the evidence at multiple spatial scales. Biological Conservation 115:101-110.

Temple, S. A., and J. R. Cary. 1988. Modeling dynamics of habitat-interior bird populations in fragmented landscapes. Conservation Biology 2:340-347.

Tewksbury, J. J., T. E. Martin, S. J. Hejl, T. S. Redman, and F. J. Wheeler. 1999. Cowbirds in a western valley: effects of landscape structure, vegetation and host density. Studies in Avian Biology 18:23-33.

Thompson, F. R., III, T. M. Donovan, R. M. DeGraaf, J. Faaborg, and S. K. Robinson. 2002. A multi-scale perspective of the effects of forest fragmentation on birds in eastern forests. Studies in Avian Biology 25:8-19.

Thompson, F. R., III, S. K. Robinson, T. M. Donovan, J. R. Faaborg, D. R. Whitehead, and D. R. Larsen. 2000. Biogeographic, landscape, and local factors affecting cowbird abundance and host parasitism levels. Pages 271-279 in J. 
N. M. Smith, T. Cook, S. I. Rothstein, S. K. Robinson, and S. G. Sealy, editors. Ecology and management of cowbirds and their hosts. University of Texas Press, Austin, Texas, USA.

Trine, C. L. 1998. Wood Thrush population sinks and implications for the scale of regional conservation strategies. Conservation Biology 12:576-585.

Van Horn, M. A., and T. M. Donovan. 1994. Ovenbird (Seiurus aurocapillus). In A. Poole and F. Gill, editors. Birds of North America, Number 88. Academy of Natural Sciences, Philadelphia, Pennsylvania, USA, and American Ornithologists' Union, Washington, D.C., USA.

Van Horn, M. A., R. M. Gentry, and J. Faaborg. 1995. Patterns of Ovenbird (Seiurus aurocapillus) pairing success in Missouri forest tracts. Auk 112:98-106.
Villard, M.-A., P. R. Martin, and C. G. Drummond. 1993. Habitat fragmentation and pairing success in the Ovenbird (Seiurus aurocapillus). Auk 110:759-768.

Vogelmann, J. E., S. M. Howard, L. Yang, C. R. Larson, B. K. Wylie, and N. Van Driel. 2001. Completion of the 1990s National Land Cover Data set for the conterminous United States from Landsat Thematic Mapper data and ancillary data sources. Photogrammetric Engineering and Remote Sensing 67:650-662.

Wilcove, D. S. 1985. Nest predation in forest tracts and the decline of migratory songbirds. Ecology 66:1211-1214.

With, K. A., and A. W. King. 2001. Analysis of landscape sources and sinks: the effect of spatial pattern on avian demography. Biological Conservation 100:75-88.

\section{APPENDIX A}

A description of the procedure used to assess how representative BBIRD sites were of overall conditions of forest fragmentation across the United States is available in ESA's Electronic Data Archive: Ecological Archives A015-043-A1.

\section{APPENDIX B}

A summary of selected forest patch, landscape, land cover, and biogeographic statistics for each of the 30 BBIRD sites we used is available in ESA's Electronic Data Archive: Ecological Archives A015-043-A2.

\section{APPENDIX C}

Demographic data used to calculate annual fecundity for the 22 species for which we had nesting success data are available in ESA's Electronic Data Archive: Ecological Archives A015-043-A3. 